\title{
A method of preparation of osteological specimens of mammals and birds
}

\author{
Vyacheslav A. Solov'ev*, Aleksei A. Sergeyev, Andrei S. Zhiryakov \\ \& Tat'yana L. Rukavishnikova
}

\begin{abstract}
It is offered a simple and effective method of osteological samples preparation of mammals and birds which does not need significant economical expenses and useful for mass analyses of biological samples. The laboratory way of vertebrate skeletons preparation offered can be used in scientific research work, museums, hunting trophies preparation as well as in veterinary and sanitary works, criminalistics, judicial and custom practices.
\end{abstract}

KEY WORDS: skull, skeleton, bones, lab work, chemical maceration, borax.

Vyacheslav A. Solov'ev [solo_vjatka@mail.ru], Aleksei A. Sergeyev[metalbird@mail.ru],Tat'yana L.Rukavishnikova, Departament of Animal Ecology, Prof. B.M. Zhitkov Russian Research Institute on Game Management and Fur Farming (VNIIOZ), ul. Preobrazhenskaja 79, Kirov 610000, Russia; Andrei S. Zhiryakov, Departament of Plant Ecology, Prof. B.M. Zhitkov Russian Research Institute on Game Management and Fur Farming, ul. Preobrazhenskaja 79, Kirov 610000, Russia.

\section{Методика обработки остеологического материала от млекопитающих и птиц}

\section{В.А. Соловьёв* ${ }^{*}$ А.А. Сергеев, А.С. Жиряков, Т.Л. Рукавишникова}

РЕЗЮМЕ. Предложена простая и эффективная методика обработки остеологического материала от млекопитающих и птиц, не требующая значительных экономических затрат и пригодная для массовой обработки биопроб. Предложенный способ лабораторной подготовки скелетов позвоночных может найти применение в научно-исследовательской работе, музейном деле, обработке охотничьих трофеев, а также в ветеринарно-санитарной, криминалистической, судебной и таможенной экспертизе.

КЛЮЧЕВЫЕ СЛОВА: череп, скелет, кости, лабораторная обработка, химическая мацерация, боракс.

\section{Introduction}

A skeleton of any vertebrates clearly represents the ecological peculiarities of the species and contains important systematic features. Skulls of hunting animals represent a special value for collection, exposure and trophy. As other elements of vertebrate skeleton they are used in veterinary-sanitary, criminalistics and judicial practice to obtain species information for the analyzed meat products; as to reveal biological remnants due to investigation cases of poaching and other crimes; for derivate identification and products of animal origin due to custom expertise and so on. Herewith, the use of bone remnants as indicators is much cheaper and more available in comparison to expensive and time-consuming genetic expertise. The quality of collected bone material, its safety and esthetically attractive exterior most of all depends on its preparation. So, a challenge appears to choose effective and at the same time cheap way of skull and bones cleaning from soft tissues for mammals, birds and other animals.

\section{Materials, tools and equipment}

While elaboration on the method of skeleton cleaning from soft tissues data from eleven mammal species and one bird species have been used (Tab. 1). We processed 142 skulls and postcranial skeletons by experimental method of chemical maceration. The material was used in fresh, rotten and frozen form. Weighting was implemented with electronic platform scales MT 0.6 V1DA-0/U with measure limits within 0.2-600 $\mathrm{g}$ with sensibility of $0.1 \mathrm{~g}$, liquid volumes were measured with volumetric flask. For biomaterial dissection standard set of instruments was used: scalpels, scissors and dissection needles.

In experiment glass chemical vessels were used during thermostat preparation and aluminum ones - 
Table 1. Number of treated biological material.

\begin{tabular}{|c|c|c|}
\hline Common name & Scientific name & $\begin{array}{l}\text { No. of } \\
\text { speci- } \\
\text { mens }\end{array}$ \\
\hline Wolf & Canis lupus L., 1758 & 1 \\
\hline $\begin{array}{l}\text { European } \\
\text { badger }\end{array}$ & Meles meles L., 1758 & 35 \\
\hline Asian badger & $\begin{array}{l}\text { Meles leucurus Hodgson, } \\
1847\end{array}$ & 11 \\
\hline Bobak marmot & $\begin{array}{l}\text { Marmota bobak Müller, } \\
1776\end{array}$ & 1 \\
\hline $\begin{array}{l}\text { Common } \\
\text { muskrat }\end{array}$ & $\begin{array}{l}\text { Ondatra zibethicus Link, } \\
1795\end{array}$ & 35 \\
\hline Raccoon dog & $\begin{array}{l}\text { Nyctereutes procyonoides } \\
\text { Gray, } 1834\end{array}$ & 4 \\
\hline Red fox & Vulpes vulpes L., 1758 & 2 \\
\hline Eurasian beaver & Castor fiber L., 1758 & 8 \\
\hline $\begin{array}{l}\text { European pine } \\
\text { marten }\end{array}$ & Martes martes L., 1758 & 3 \\
\hline $\begin{array}{l}\text { European } \\
\text { polecat }\end{array}$ & Mustela putorius L., 1758 & 5 \\
\hline American mink & $\begin{array}{l}\text { Neovison vison Schreber, } \\
1777\end{array}$ & 2 \\
\hline Hazel grouse & Bonasa bonasia L., 1758 & 34 \\
\hline $\begin{array}{l}\text { Herb field } \\
\text { mouse }\end{array}$ & $\begin{array}{l}\text { Apodemus uralensis Pallas, } \\
1811\end{array}$ & 1 \\
\hline
\end{tabular}

while boiling. Skull boiling was made on electrical twoburner stove "Novovyatka". Preparation table equipment used is shown on Fig. 1.

Statistical processing of the data obtained was carried out with a computer program «Biostatistics 4.03» by standard methods.

\section{Results and discussion}

It is known a few main methods of skulls and bones preparation in laboratory such as: boiling in water, maceration by rotting, cleaning with protein enzymes solution, and cleaning by dermestid beetles larvae. Most of these methods have not only advantages, but also sufficient disadvantages limiting possibility of their use.

\section{Boiling}

This is the most wide-spread method in laboratory practice as well, as during hunting trophies treatment. Its main positive characteristics are its relative simplicity and availability. Skull preparation by boiling is quite laborious and needs more time and power. It is well known that while brewing of craniological material destruction of teeth and cartilaginous parts of a skull is quite often. Besides, during final cleaning of the con-

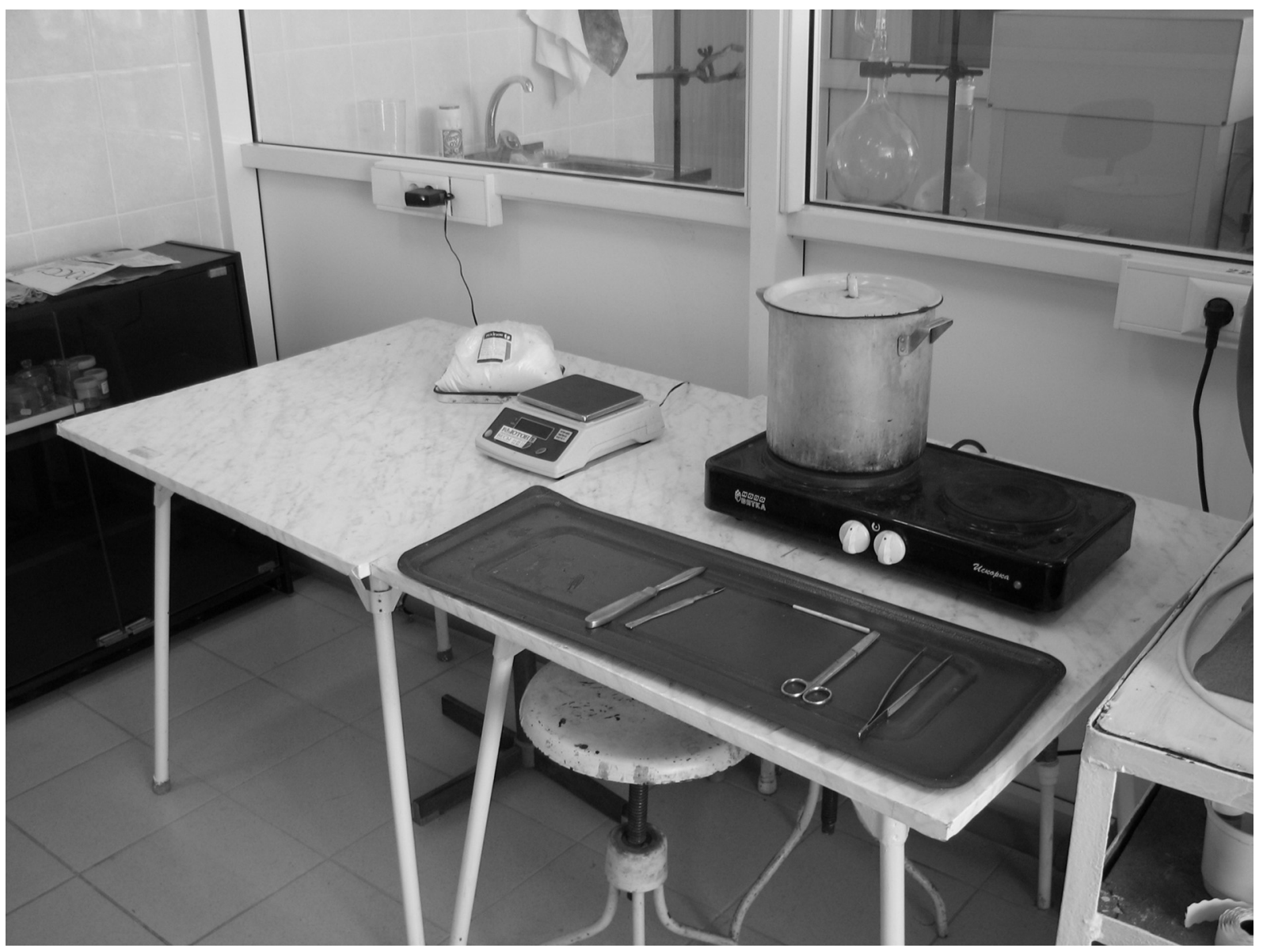

Figure 1. Working table equipment for osteological material preparation. 
junctive tissue one has to use sharp instruments, which can cause an accidental damage to the bones surfaces. During cleaning the destruction of its small parts happens quite often even if it is professionally made. Removing small tissues from boiled skull takes from 30 min to 10 hours and more, depending on species, sizes, animal age, as well as the staff skills.

\section{Maceration by rotting}

The use of this method needs special laboratory conditions, as during the process of bones cleaning for 2-3 weeks strong unpleasant smell is emitted. Using agar-agar solution and other agents (Zaslavskii, 1980) does not solve the problem completely. To work with this material is quite unpleasant and sometimes even dangerous without special protective facilities. Besides, during natural maceration due to occasional rancid fat falls on the bones the external view of osteological material is only getting worse, which is difficult for degrease and bleaching.

\section{Protein enzymes solutions treatment}

This technique is based on natural process of digestion during which soft tissues are being macerated by means of artificial trypsin and papain. The method is quite effective but not always practical because needs special agents and conditions of their use. Main disadvantage is damage causing by enzymes to the internal part of the bones, after their use it is quite problematical to define the age of the animal by bones and teeth cuts.

\section{Dermestid beetles larvae use (Dermestes sp.)}

Very effective way of vertebrate skeleton cleaning, however it demands permanent insects' colonies control. It is necessary not only to keep their sufficient number but also to provide full isolation of exhibits from the colonies. Osteological material cleaning by this method needs more time and attention, for the larvae can damage cartilage joints and even bones. Therefore, because of above-mentioned reasons this method is mostly used in the museums with vast collections.

After using any of these methods bones degreasing and bleaching are needed. Usually degreasing is made with trichloroethylene solution, alcohol or acetone, and bleaching — with hydrogen peroxide or ammonia hydroxide.

\section{Chemical maceration}

There are also methods of mammals bone cleaning with chemicals. During artificial maceration of bone tissue in industrial conditions ammonia and chromic acid are widely used, however they affect osteological material's hardness and integrity and do not provide full safety for recording structures. Recently patented in the Great Britain method of animals' corpses decomposition - resomation - based on alkaline hydrolyses reaction. This process reminds natural decomposition and takes only 2-3 hours (http://www.resomation.com).
Researchers from the Faculty of zoology and ecology of the Kemerovo State University use the caustic soda for cleaning of skeletons of insectivores (Ilyashenko \& Onishchenko, 1999). The method offered here is very effective especially to the skeletons of small vertebrates, but using a quite dangerous chemical agent for middle-sized and large animals osteological material processing is quite troublesome.

High effectiveness for small and middle-sized mammals skulls cleaning showed sodium tetrahydrate perborate $\left(\mathrm{NaBO}_{3} * 4 \cdot \mathrm{H}_{2} \mathrm{O}\right)(\mathrm{McD}$ onald \& Vaughan, 1999). In Russia the price of this chemical is expensive, that was a reason of our search for more affordable and quite effective analogue.

While searching it was discovered that for lab cleaning of skulls and postcranial skeletons for mammals and small and middle-sized birds the sodium decahydrate tetraborate $\left(\mathrm{Na}_{2} \mathrm{~B}_{4} \mathrm{O}_{7} * 10 \cdot \mathrm{H}_{2} \mathrm{O}\right)$ known as borax can be used. This substance is not expensive and easily can be found in shops and chemical laboratories. In industry borax is particularly used for disinfection. The latter is especially important, because one has to deal with decomposing and rotting material.

It was made an assessment for possibility to use the given method for different animal species, with different sizes and ages, possible limitations were checked during work with fresh and pathological samples for the purpose to create the most effective technology, various regimes for samples' processing were defined as well, as acceptable equipment was singled out.

\section{Osteological samples technology}

First to prepare sodium dehydrate tetraborate working solution you dissolve its known mass thoroughly in water under $70-80^{\circ} \mathrm{C}$ until its complete dissolution to prevent clods. White crystals of borax are well hydrolyzed and the obtained solution shows alkaline reaction.

To speed up the process before placement the samples into solution it is recommended to remove feather, skin and easy removable parts of muscles. Prepared material in fresh or frozen condition must be fully placed into the solution. Average material use rates are given in Tab. 2, however they can vary depending on sex, age and sizes of examined animals as well, as on material freshness.

Thermal treatment occurs in thermostat under the temperature below $80-90^{\circ} \mathrm{C}$. Between the temperature of the process and its duration authentic inverse correlation can be noticed as: $\mathrm{r}=-0.59, \mathrm{t}=-463, \mathrm{P} \leq 0.01$, $n=42$. The exposure time also depends on solution concentration. Under the temperature of $50^{\circ} \mathrm{C}$ tissue maceration did not occur regardless of exposure time and borax concentration, which was increased to $29.2 \%$ during tests. In $5 \%$ solution under $65^{\circ} \mathrm{C}$ temperature tissue maceration was observed, but the process was slow and did not finish in 27 hours during continuous thermostat exposure.

Increasing of temperature up to $70^{\circ} \mathrm{C}$ had activated the process, which was completely finished in 24 hours. 
Table 2. Optimal treatment regimes of osteological material from some wild animals.

\begin{tabular}{|l|c|c|c|c|}
\hline \multicolumn{1}{|c|}{ Material } & $\begin{array}{c}\text { Solution volume, } \\
\text { liter per sample }\end{array}$ & $\begin{array}{c}\text { Borax concentration } \\
\text { in solution, } \%\end{array}$ & $\begin{array}{c}\text { Temperature, } \\
{ }^{\circ} \mathrm{C}\end{array}$ & $\begin{array}{c}\text { Exposure time, } \\
\text { hours }\end{array}$ \\
\hline Badger, fox, raccoon dog & 0.7 & 10.0 & $85^{\circ}$ & $16.0-24.0$ \\
\hline Mink, polecat & 0.3 & 10.0 & $80^{\circ}$ & $14.0-18.0$ \\
\hline Muskrat & 0.2 & 10.0 & $70^{\circ}$ & $12.0-16.0$ \\
\hline $\begin{array}{l}\text { Juvenile individuals of } \\
\text { mammals }\end{array}$ & $0.7-0.1$ & 5.0 & $60^{\circ}$ & $2.5-3.0$ \\
\hline Hazel grouse & 0.1 & 13.0 & $60^{\circ}$ & 2.5 \\
\hline Badger, express method & 0.7 & 3.3 & $100^{\circ}$ & 3.0 \\
\hline
\end{tabular}

You should notice that the time needed for tissue separation from bones can vary from $30-70 \%$ depending on animal species and age, and for big animals it could be even more.

While processing one has to pay attention that due to solution surplus and long time treatment skull bones could separate from each other. At the same time, solution concentration decrease and time of the exposure, on the other hand, can lead to bad skulls processing and it will be difficult to clean them completely.

One does not need to be afraid of adult individuals' skulls over-exposure. As due to the process only lower jaw bones can be separated, which can be glued together. Over-exposing of young individuals' skulls can cause loosing of nasal bones. Separation of other cranial bones connections of middle-sized mammals was not observed.

Skull bones of very young individuals have cartilaginous connections; therefore their processing must be very careful with permanent control. Thus, after skulls processing of $2-3$ months old beavers in $8 \%$ borax solution during 12 hours under $80^{\circ} \mathrm{C}$ temperature they were disconnected along all the skull seams and joints and were not able to get restored. It is necessary to take into consideration that time needed for rotten material maceration must be less than for the fresh one processing especially if it belongs to birds (Fig. 2).

At the end of maceration muscle tissue becomes very soft and easily detachable from the bones. Skulls' cleaning is made hydro-mechanically over a metallic sieve under moderate water stream.

Soft tissues left in the sieve are disposed after careful check for small bones and teeth. It is better to clean cartilaginous parts of skulls of big-sized animals with medical tweezers. Brain is extracted by mixing it until mashed and washing under a strong stream/jet through nape foramen. To finish a process of skull cleaning from muscles and connective tissues it is recommended to make under water stream with rough-bristled brush. In this case we used a toothbrush with which you can easily and effectively clean hard-to-reach places from tissues remains without any scratches. After bones processing in tetraborate solution their degreasing and bleaching is not necessary. As bones having been dried on air small bones and teeth are glued (Figs 3-5).

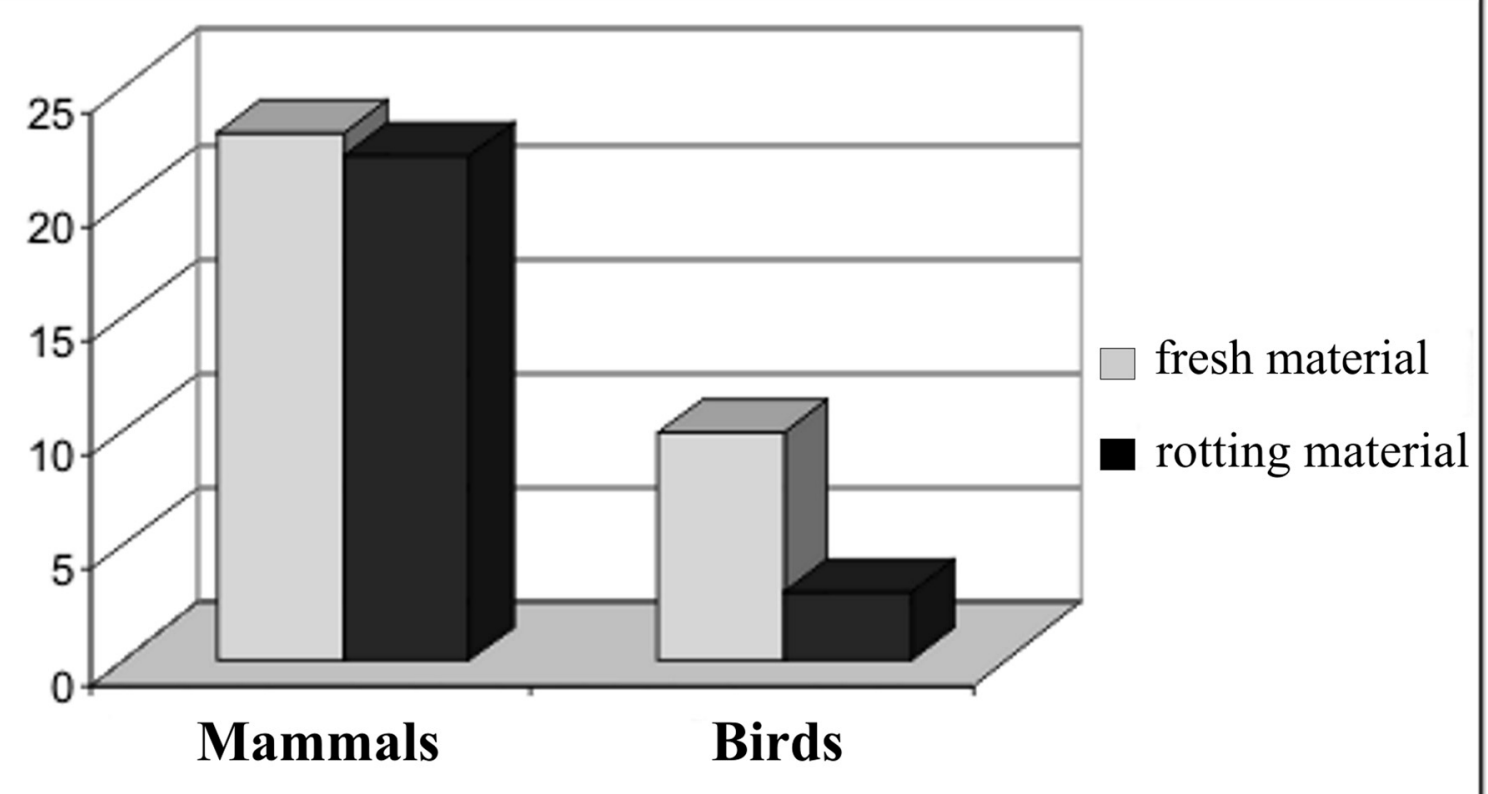

Figure 2. Preparation time (hours) of fresh material and first stages of rotting material from small and middle-sized mammals and birds under $60^{\circ} \mathrm{C}$ temperature in $13 \%$ borax solution. 


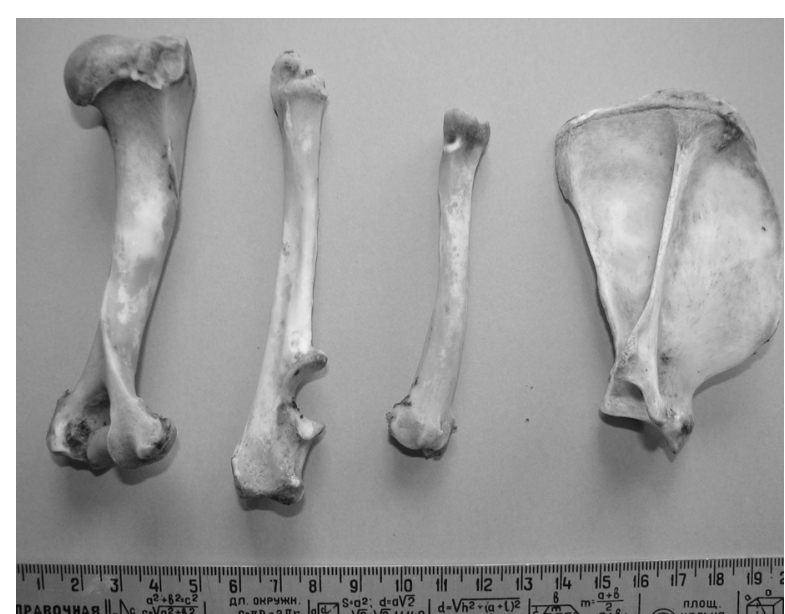

Figure 3. Badger osteological material.

\section{ing}

Express-method of osteological samples process-

In case when it is strictly needed to prepare osteological samples very quickly it is possible to put samples under $100^{\circ} \mathrm{C}$ temperature. Concentration of borax in this situation is getting lower to $3 \%$, however process time is noticeably cut (Tab. 2). By reducing the concentration of the solution to $1.5 \%$ soft tissues removal after a three-hour exposure was still difficult. Concentration increase to $5-9 \%$ did not decrease the time and did not improve samples preparation effectiveness.

After badger's skull boiling in fresh water without borax during $3 \mathrm{~h} 25$ min muscle tissue has been separated with difficulty by scalpel and in the places of connective tissues one had to use more power, which could cause damage to the processed bones. Old animals'

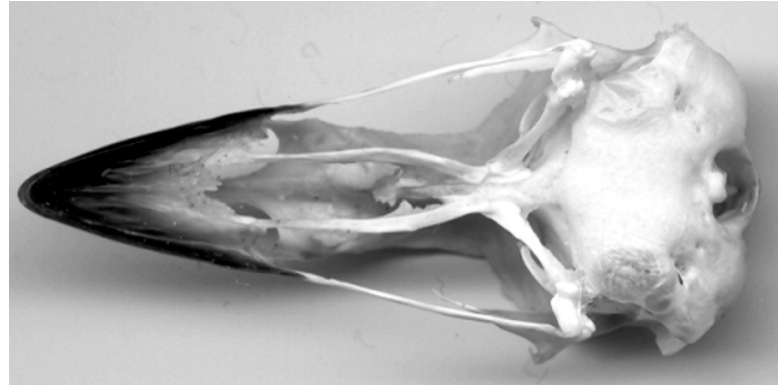

Figure 5. Hazel grouse skull processed by the method described above. It is well seen that thin bones are not damaged.

skulls can be cleaned well only after 5-10 hours of boiling in normal water. If $3.3 \%$ borax solution is used under $100^{\circ} \mathrm{C}$ temperature muscle tissue maceration is completely finished in 3 hours.

Thermostat maceration is longer, but needs less attention. During exposure under $100^{\circ} \mathrm{C}$ temperature one had to check solution level and regularly add water because of its evaporation. It is very important that a vessel with the boiling material is covered with liquid. Otherwise, reaction speed is getting lower.

After thermal preparation finished all further operations are made by the above-described method.

Estimation of time required for skull samples cleaning with the help of fixation and measure of work duration showed a great advantage of express method in comparison with traditional way of treatment by boiling (Fig. 6) mainly due to thermo preparation and soft tissue separation processes durations decrease.

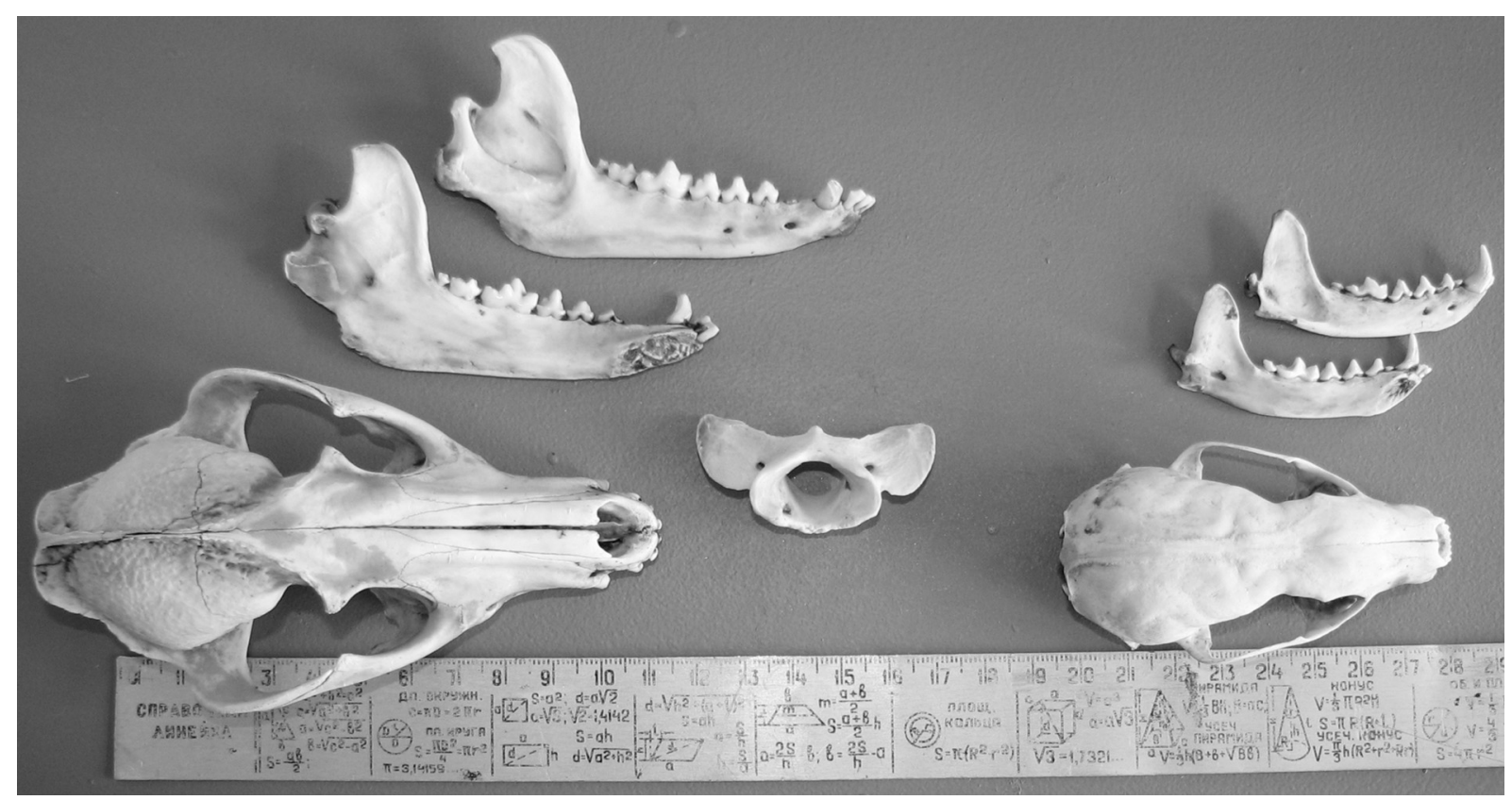

Figure 4. Raccoon dog (left) and pine marten (right) skulls after borax treatment and soft tissues separation under water stream. 


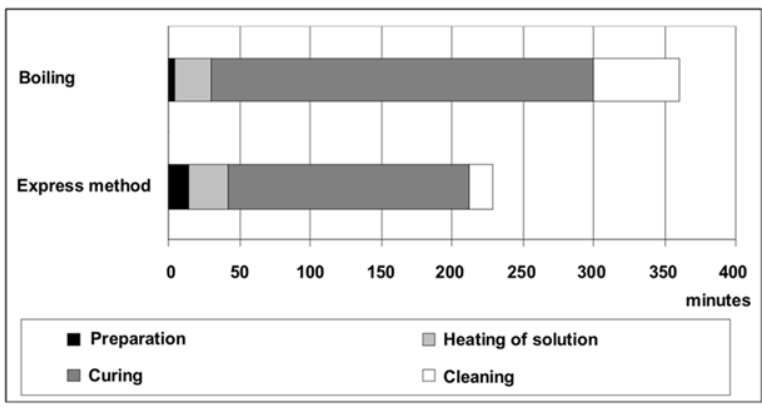

Figure 6. Timing of mammalian skulls clearing operations at boiling down and express method of chemical maceration with the use of borax and hydro-mechanical clearing.

Average time for skull processing of $200-400 \mathrm{~g}$ sample by express method is $231.2 \pm 3.42 \mathrm{~min}$ (Tab. 3), including tissues remains disposal, weighing of necessary amount of a preparation, preliminary solution heating, boiling and hydro mechanic cleaning of samples.

\section{Conclusion}

The method of osteological samples processing does not require a lot of physical and economical expenses. It is simple in use and allows getting high quality samples in short time and together with it good for mass biomaterial preparation. With accurate work even the smallest fragile bones could be safe. According to preliminary search results of histological cuts of badger lower tusks the growth rings are well seen and can be used for age estimation. The suggested method can be used for laboratory biomaterial treatment for the purpose of zoological collections creation, in veterinary and sanitary work and criminalistics expertise, for hunting trophies preparation and so on.
Table 3. Chronometry of badger skulls treatment procedures with express-method use, min.

\begin{tabular}{|l|c|c|c|}
\hline \multicolumn{1}{|c|}{ Stage } & $n$ & $\mathrm{M} \pm \mathrm{m}$ & $\lim$ \\
\hline Preparation & 6 & $14 \pm 1.15$ & $10-17$ \\
\hline Solution heating & 6 & $28.23 \pm 2.52$ & $23-40$ \\
\hline $\begin{array}{l}\text { Solution thermal } \\
\text { treatment }\end{array}$ & 6 & $170 \pm 0$ & $170-170$ \\
\hline $\begin{array}{l}\text { Mechanic soft } \\
\text { tissues separation }\end{array}$ & 10 & $16.6 \pm 1.32$ & $11-23$ \\
\hline
\end{tabular}

ACKNOWLEDGEMENTS. Authors are grateful to Dr. Alexei V. Abramov (Zoological Institute of the Russian Academy of Sciences, Saint-Petersburg) for information support, and also to Sergey Fominyh (Vyatka State Agricultural Academy, Kirov) for the technical help during lab works. Special thanks to reviewers for their hard work, Dr. A.P. Saveljev and Dr. N.R. Bogatyrev for help in translating this article.

\section{References}

Ilyashenko V.B. \& Onishchenko S.S. 1999. [The method of shrews skeletons clearing] // Biologiya Nasekomoyadnykh Mlekopitayushchikh. Materialy Mezhdunarodnoi Konferentsii. Kemerovo: Kuzbassvuzizdat. P.103-105 [in Russian].

McDonald R.A. \& Vaughan N. 1999. An efficient way to prepare mammalian skulls and bones // Mammal Review. Vol.29. No.4. P.265-266.

Solovyev V.A., Sergeyev A.A., Zhiryakov A.S. \& Fominykh S.V. 2007. [An efficient way to prepare osteological samples from mammals and birds] // Shiryaev V.V. (ed.). Sovremennye Problemy Prirodopol'zovaniya, Okhotovedeniya i Zverovodstva. Materialy Mezhdunarodnoi Nauchno-Prakticheskoi Konferentsii, Posvyashchennoi 85-letiyu VNIIOZ (22-25 maya 2007 goda). Kirov: VNIIOZ. P.411-412 [in Russian with English summary].

Zaslavskii M.A. 1980. [Preparation of trophies] // Okhota i Okhotnichie Khozyaistvo. No.1. P.10-12 [in Russian]. 